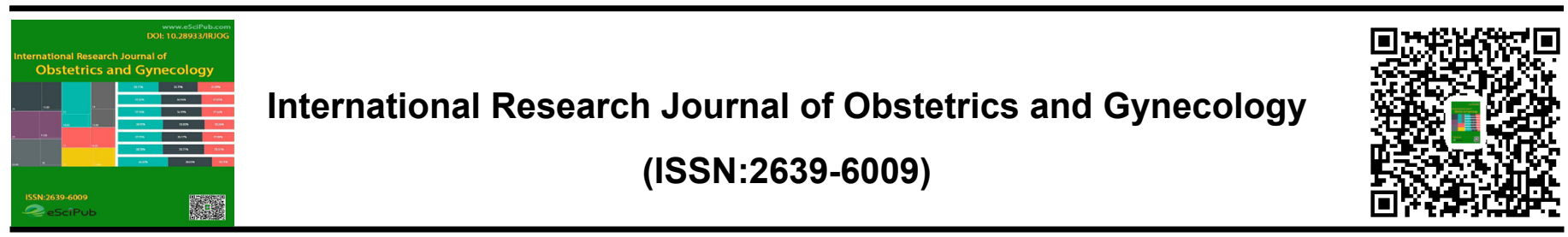

\title{
HPV-NEGATIVE VULVAR SQUAMOUS CELL CARCINOMA IN A 21-YEAR-OLD PATIENT
}

\author{
Dânia Ferreira ${ }^{1^{*}}$, Paulina Corgo $^{2}$, Vanda Patrício ${ }^{3}$, Amelia de Almeida $^{4}$ \\ ${ }^{1}$ Hospital de Braga. ${ }^{2}$ Centro Hospitalar Medio Ave, Famalicão. ${ }^{3}$ Instituto Português de Oncologia \\ do Porto. ${ }^{4}$ Centro Hospitalar Medio Ave, Famalicão.
}

\begin{abstract}
Vulvar Squamous Cell Carcinoma usually occurs among women in their 60s or 70s. There are a limited number of reports of

${ }^{*}$ Correspondence to Author:

vulvar cancer cases younger than 30 years. These patients Dânia Ferreira

have usually risk factors such as human papillomavirus (HPV) infection.

In this report, the authors present a rare case of invasive vulvar How to cite this article:

squamous cell carcinoma in a 21-year-old patient without HPV Dânia Ferreira, Paulina Corgo, infection. Surgical treatment was performed, followed by adjuvant Vanda Patrício, Amelia de Almeida. radiation therapy. HPV-NEGATIVE VULVAR SQUA-

Keywords: HPV; Vulvar Squamous Cell Carcinoma MOUS CELL CARCINOMA IN A 21-YEAR-OLD PATIENT.International Research Journal of Obstetrics and Gynecology, 2021; 4:36.

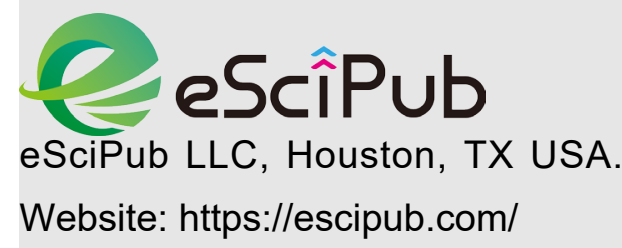




\section{BACKGROUND}

Vulvar cancer is the fourth most common gynecologic cancer (following cancer of the uterine corpus, ovary, and cervix) and comprises $5 \%$ of malignancies of the female genital tract. ${ }^{[1]}$ About $80-90 \%$ of vulvar cancers are squamous cell carcinomas (SCC), and most of them present between the ages of 60 and 74 years, being only rarely found in patients younger than 30 years. ${ }^{[2]}$

Two independent etiological pathways of vulvar carcinogenesis have been implicated in the development of vulvar cancer. In younger women, persistent mucosal infection with oncogenic human papillomavirus (HPV) leads to vulvar intraepithelial neoplasia (VIN), which is a premalignant lesion. ${ }^{[3,4]} \mathrm{HPV}$ oncoproteins E6 and E7 lead to the inactivation of tumor suppressor proteins p53 and retinoblastoma, respectively. These tumors are associated with diffuse expression of $p 16 .{ }^{[5]}$ In older, predominantly post-menopausal women, cancer arises in vulvar skin affected by non-neoplastic epithelial disorders such as vulvar inflammation, lichen sclerosus or squamous cell hyperplasia. [6] These vulvar squamous cell carcinomas are considered "HPV independent" and are associ- ated with chronic inflammation such as lichen sclerosis or autoimmune processes. ${ }^{[7]}$

\section{CASE PRESENTATION}

A 21-year-old female and caucasian patient presented to Out-Patient Department of Gynaecology with complaints of a progressive vulvar mass with intense pruritus and burning sensation with about 12 months of evolution. The patient reported never having had sexual intercourse. Her past medical history revealed an insidious vulvar pruritus since puberty. There was no history of smoking and known systemic autoimmune or genetic diseases. There was no history of genital malignancy in the family.

On gynaecological examination, vagina, cervix and uterus appeared normal, whereas a warty midline tumour mass of $5 \times 3 \mathrm{~cm}$ involving the clitoris and both the right and left majus and minus labium was documented (figure 1). At the lower half of the vulva and perineum, she presented a diffuse pallor of the skin, with smooth glistening areas and signs of atrophy, with obliteration of the labia minora and stenosis of the introitus, clinically suggestive of lichen sclerosus. The inguinal lymph nodes weren't palpably enlarged.

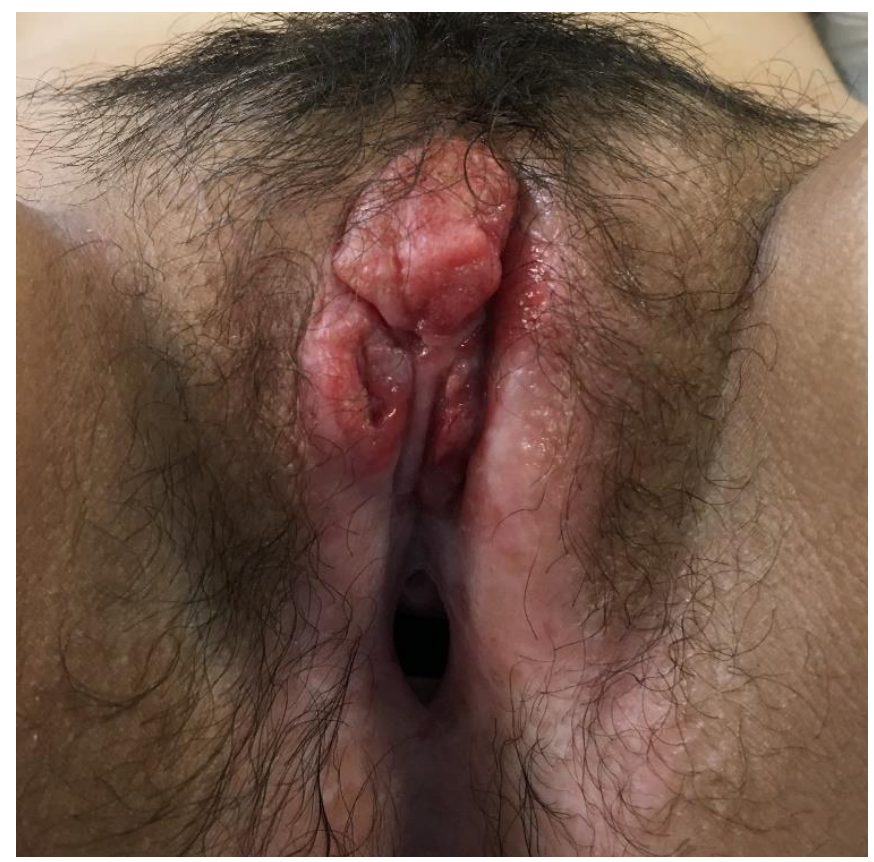

Figure 1: Local gyn examination showed a warty midline tumour mass of $5 \times 3 \mathrm{~cm}$ involving the clitoris and both the right and left majus and minus labium. At the lower half of the vulva and perineum, she presented a diffuse pallor of the skin, with smooth glistening areas and signs of atrophy, with obliteration of the labia minora and stenosis of the introitus, clinically suggestive of lichen sclerosus. 
Biopsies of the lesion documented a well differentiated invasive vulvar squamous cell carcinoma with lichen sclerosus areas. HPV Real time PCR was found negative and PAP smear was negative for intraepithelial lesions or malignancy. Patient was negative for HIV infection.

Staging work-up, including chest X-rays, and abdominal and pelvic CT scan, did not show any sign of distant sites of disease. Karyotype was 46, XX.

Surgical treatment was performed one month later. Radical anterior and superficial posterior hemivulvectomy plus bilateral inguinofemoral lymphadenectomy were performed. Althoug the patient had no suspicion of lymph node involvement during examination and imaging, she did not meet other criteria for sentinel lymph node biopsy considering tumor size was larger than 4 $\mathrm{cm}$.

The histology revealed a well differentiated invasive vulvar squamous cell carcinoma measuring $5 \times 4 \mathrm{~cm}$, with a thickness of $9 \mathrm{~mm}$, located in the clitoral area, with no lymphovascular invasion but with perineural invasion. All margins were free of tumour, althought in one of them the surgical tumor-free margin was 3 $\mathrm{mm}$ on tissue section. None of the inguinal lymph nodes revealed metastasis. The final staging was a stage IB vulvar squamous cell carcinoma - the lesion was $>2 \mathrm{~cm}$ in size, confined to the vulva, with negative lymph nodes - according to FIGO staging for vulvar cancer 2009.

Considering the young age of the patient and the state of the surgical margins (a margin distance less than $8 \mathrm{~mm}$ ) she received adjuvant radiation therapy to improve local control rate and possibly overall survival.

No evidence of recurrence was seen over a follow-up period of 18 months.

The final staging was a stage IB vulvar squamous cell carcinoma, according to FIGO staging for vulvar cancer 2009. As the patient had one surgical tumor-free margin less than 8 $\mathrm{mm}$ on tissue section, she received adjuvant radiation therapy. No evidence of recurrence or lymphedema of the lower limbs were seen over a follow-up period of 18 months

\section{DISCUSSION}

In the literature, very few cases of invasive vulvar carcinoma diagnosed at such young ages are reported (table 1):

\begin{tabular}{|c|c|c|c|c|}
\hline Article & $\begin{array}{c}\text { Year of } \\
\text { publication }\end{array}$ & $\begin{array}{c}\text { Age of } \\
\text { diagnosis }\end{array}$ & Presentation & Main findings \\
\hline $\begin{array}{l}\text { Kaur P, Bhatia R, Dev Singh } \\
\text { A, Gupta R. Squamous Cell } \\
\text { Carcinoma Vulva in a Young } \\
\text { Woman - case report. Annals } \\
\text { of Applied Bio-Sciences. }{ }^{8]}\end{array}$ & 2016 & 36 & $\begin{array}{l}\text { Intense vulval } \\
\text { itching and burning } \\
\text { sensation with } \\
\text { dysuria and burning } \\
\text { micturition. } 5 \times 4 \mathrm{~cm} \\
\text { angry red, } \\
\text { ulcerated, oozing } \\
\text { lesion on the upper } \\
\text { part of right labia } \\
\text { majora and minora. }\end{array}$ & $\begin{array}{l}\text { Moderately differentiated } \\
\text { keratinizing squamous cell } \\
\text { carcinoma of the vulva. No } \\
\text { history of cigarette smoking, } \\
\text { vulvar dystrophy, vulvar or } \\
\text { cervical intraepithelial } \\
\text { neoplasia, human } \\
\text { papillomavirus infection, or } \\
\text { immunodeficiency } \\
\text { syndromes. }\end{array}$ \\
\hline $\begin{array}{l}\text { Mohan Rao TS, Bellam SS, } \\
\text { Gurupuprasad P. Vulvar } \\
\text { invasive squamous cell } \\
\text { carcinoma in a young patient } \\
\text { with Human Immunodeficiency } \\
\text { Virus-seropositivity. } \\
\text { Indian Journal of Sexually } \\
\text { Transmitted Diseases and } \\
\text { AIDS. }{ }^{[9]}\end{array}$ & 2015 & 29 & $\begin{array}{l}\text { A nonhealing ulcer } \\
\text { on the vulva of } 4 \\
\text { months duration, } \\
\text { with severe itching } \\
\text { and burning } \\
\text { sensation. } \\
\text { Erythematous } \\
\text { verrucous } \\
\text { indurated growth } \\
\text { measuring about } 2\end{array}$ & $\begin{array}{l}\text { Focally invasive moderately } \\
\text { differentiated squamous cell } \\
\text { carcinoma of the vulva. } \\
\text { Laboratory studies confirmed } \\
\text { immunosuppression caused } \\
\text { by HIV infection. }\end{array}$ \\
\hline
\end{tabular}




\begin{tabular}{|c|c|c|c|c|}
\hline & & & $\begin{array}{l}\mathrm{cm} \times 1 \mathrm{~cm} \text { over the } \\
\text { right side of labia } \\
\text { majora. }\end{array}$ & \\
\hline $\begin{array}{l}\text { Echeverri C, Stoler MH, } \\
\text { Valente PT. Vulvar } \\
\text { Keratinizing Squamous Cell } \\
\text { Carcinoma in a } 26 \text {-Year-Old } \\
\text { Woman. } \\
\text { Archives of Pathology \& } \\
\text { Laboratory Medicine Online. } \\
\text { [10] }\end{array}$ & 2001 & 26 & $\begin{array}{l}\text { "Itching" and } \\
\text { "herpetic lesions" } \\
\text { on the vulva for } 9 \\
\text { months. A total of } 4 \\
\text { vulvar lesions were } \\
\text { visible, located on } \\
\text { both labia majora } \\
\text { and the mons } \\
\text { pubis. The largest } \\
\text { lesion was located } \\
\text { in the mons pubis } \\
\text { and measured } \\
5.5 \mathrm{~cm} .\end{array}$ & $\begin{array}{l}\text { Well-differentiated } \\
\text { keratinizing invasive } \\
\text { squamous cell carcinoma of } \\
\text { the vulva. Testing were } \\
\text { negative for HPV and HIV } \\
\text { infection. }\end{array}$ \\
\hline $\begin{array}{l}\text { Kahramanoglu I et al. A Very } \\
\text { Rare Case: HPV-Negative } \\
\text { Vulvar Cancer in an } \\
\text { Adolescent. } \\
\text { Case Reports in Obstetrics } \\
\text { and Gynecology. }{ }^{[11]}\end{array}$ & 2018 & 18 & $\begin{array}{l}\text { Pruritic, painful } \\
\text { lesion on the vulva. } \\
\text { A hyperpigmented } \\
\text { and erosive lesion, } \\
2 \mathrm{~cm} \text { in diameter, } \\
\text { centrally localized } \\
\text { in the vulva }\end{array}$ & $\begin{array}{l}\text { Keratinizing invasive } \\
\text { squamous cell carcinoma of } \\
\text { the vulva. } \\
\text { Immunohistochemical study } \\
\text { for HPV in vulvar excision } \\
\text { specimen were negative. } \\
\text { No evidence of any } \\
\text { immunosuppressive } \\
\text { condition or tobacco use. }\end{array}$ \\
\hline
\end{tabular}

Several findings make this case of vulvar squamous cell carcinoma quite unusual. This patient was only 21 years old at diagnosis, which is far below the mean age of diagnosis of vulvar cancer. Although the incidence of vulvar intraepithelial neoplasia (VIN) caused by HPV infection has increased during recent years, there have been only a few reported cases of invasive SCC in such young women. Actually, evidence suggests that only about $15 \%$ of vulvar tumors occur in women less than 40 years. ${ }^{[12]}$

In contrast to other cases reported in the literature, our patient did not present HPV infection. Young women usually have basaloid or warty-type tumors, which are associated with HPV. In contrast, our patient, despite her age, had the type of tumor seen in the older women (keratinizing type) and it was HPV negative by PCR studies.

In addition to the uncommon age, this presentation is also exceptional due to patient's history of a chronic vulvar pruritus since puberty, which has been consistent with chronic vulvar inflammation, possibly lichen sclerosus, that has been underdiagnosed and undertreated. Although it is more frequent in postmenopausal women, the other peak of incidence of lichen sclerosus affects about $7-15 \%$ of pre-pubertal population. $[13,14]$ Lichen sclerosus is thought to be a predisposing factor in the development of HPVnegative vulvar cancer. According to the "itchscratch-lichen sclerosus hypothesis," lichen sclerosus, by causing a severe pruritus, sets up an itch-scratch cycle that over time causes the development of squamous cell hyperplasia. [15] Further progression results in atypia formation, followed by VIN and eventual invasive squamous cell cancer. [16,17] Other pathogenic mechanisms that may have contributed to this vulvar carcinoma are possibly other environmental and/or genetic factors that may impaired host immunity, which still needs further investigation. Our patient had a normal karyotype, but other genetic disorders were not researched.

Given the rarity of this case and its peculiar characteristics, there is a limited understanding of its pathogenesis and even less knowledge available regarding the best clinical approach. Management of invasive vulvar cancer in such young population needs to be balanced between 
appropriate curative surgery, which will often be radical, versus the desire to perform less mutilating surgery in young women. Treatment often depends on the stage of the disease. In this stage the patient underwent modified radical vulvectomy with inguinofemoral lymphadenectomy, followed by adjuvant radiotherapy.

This case illustrates the importance of being aware of any symptoms of lichen sclerosus or other cronic inflammatory processes of the lower genital tract predisposing to vulvar cancer, even in young women. Evaluation and appropriated treatment of lichen sclerosus with topical steroids allow the relief of symptoms and prevent anatomical irreversible deformities of the genitalia, preventing, at least in theory, malignant transformation. [18] A careful regular examination of the vulva and perianal region, with biopsies of any suspicious areas, will allow an early detection of vulvar cancer in the early stages, thus improving treatment and subsequent morbidity and mortality. Early detection and biopsy of any abnormal vulvar lesions are imperative to achieve diagnosis of vulvar cancer in the early stages, regardless of patients age.

\section{CONCLUSION}

Although vulvar carcinoma is a disease of the elderly, young women may be affected.

Vulvar carcinoma in very young women may develop without HPV infection.

Lichen sclerosus is a predisposing factor in the development of HPV-negative vulvar cancer.

An awareness of the symptoms of lichen sclerosus, even in young patients, should lead to prompt investigation and early biopsy of any abnormal vulvar lesions.

In conclusion, there should be a high index of suspicion when a vulvar lesion is seen, even if the patient falls below the typical age range and does not carry any of the risk factors most seen in young women, such as HPV infection.

\section{REFERENCE}

[1] Berek J, Karam A. Vulvar cancer: Epidemiology, diagnosis, histopathology, and treatment of rare histologies. UpToDate 2018.

[2] Crum CP. Carcinoma of the vulva: epidemiology and pathogenesis. Obstet Gynecol. 1992; 79:448-454.
[3] Monk BJ, Burger RA, Lin F, et al. Prognostic significance of human papillomavirus DNA in vulvar carcinoma. Obstet Gynecol. 1995; 85:709-715.

[4] Insinga RP, Liaw KL, Johnson LG, Madeleine MM. A systematic review of the prevalence and attribution of human papillomavirus types among cervical, vaginal, and vulvar precancers and cancers in the United States. Cancer Epidemiol Biomarkers Prev 2008; 17:1611-1622.

[5] Dong F, Kojiro S, Borger DR, Growdon WB, Oliva E. Squamous cell carcinoma of the vulva: a subclassification of 97 cases by clinicopathologic, immunohistochemical, and molecular features (p16, p53, and EGFR). Am. J. Surg. Pathol. 2015; 39: 1045-1053.

[6] Scurry JP, Vanin K. Vulvar squamous cell carcinoma and lichen sclerosus. Australas $\mathrm{J}$ Dermatol. 1997, 38 (Suppl 1): S20-S25.

[7] de Koning MN, Quint WG, Pirog EC. Prevalence of mucosal and cutaneous human papilloma viruses in different histologic subtypes of vulvar carcinoma. Mod Pathol 2008; 21:334-344.

[8] Kaur P, Bhatia R, Dev Singh A, Gupta R. Squamous Cell Carcinoma Vulva in a Young Woman - case report. Annals of Applied BioSciences 2016; 3(4): 60-63.

[9] Mohan Rao TS, Bellam SS, Gurupuprasad P. Vulvar invasive squamous cell carcinoma in a young patient with Human Immunodeficiency Virus-seropositivity. Indian Journal of Sexually Transmitted Diseases and AIDS 2015; 36(2): 204-206.

[10] Echeverri C, Stoler MH, Valente PT. Vulvar Keratinizing Squamous Cell Carcinoma in a 26Year-Old Woman. Archives of Pathology \& Laboratory Medicine 2001; 125(2):267-70.

[11] Kahramanoglu I, Turan $\mathrm{H}$, et al. A Very Rare Case: HPV-Negative Vulvar Cancer in an Adolescent. Case Reports in Obstetrics and Gynecology, 2018; 2018: 1-3.

[12] Royal College of Obstetricians and Gynaecologists. Guidelines for the Diagnosis and Management of Vulvar Carcinoma. London: RCOG; 2014.

[13] Eva LJ. Screening and follow up of vulval skin disorders. Best Pract Res Clin Obstet Gynaecol. 2012; 26(2):175-188.

[14] Chi CC, Kirtschig G, Baldo M, Lewis F, Wang $\mathrm{SH}$, Wojnarowska F. Systematic review and meta-analysis of randomized controlled trials on topical interventions for genital lichen sclerosus. J Am Acad Dermatol. 2012; 67(2): 305312. 
[15] Bradford J, Fischer G. Long-term management of vulval lichen sclerosus in adult women. Aust N Z J Obstet Gynaecol. 2010; 50(2): 148-152.

[16] Madeleine MM, Daling JR, Carter JJ, et al. Cofactors with human papillomavirus in a population-based study of vulvar cancer. J Natl Cancer Inst. 1997; 89(20): 1516-1523.

[17] Scurry J. Does lichen sclerosus play a central role in the pathogenesis of human papillo- mavirus negative vulvar squamous cell carcinoma? The itch-scratch-lichen sclerosus hypothesis. Int J Gynecol Cancer. 1999; 9(2): 89-97.

[18] Cooper SM, Gao XH, Powell JJ, Wojnarowska F. Does treatment of vulvar lichen sclerosus influence its prognosis? Arch Dermatol. 2004; 140(6): 702-706.

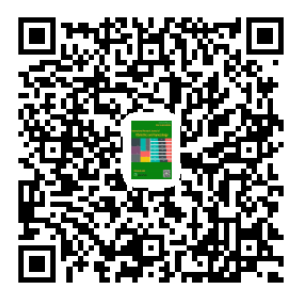

